Japan. J. Med. Sci. Biol., 20, 461-470, 1967

\title{
PASSIVE TRANSFER OF TUBERCULIN HYPERSENSITIVITY IN NEWBORN GUINEA PIGS
}

\author{
TAKESHI YOSHIDA \\ Department of Tuberculosis, National Institute of Health Tokyo
}

(Received: September 8th, 1967)

\begin{abstract}
SUMMARY : The capacity of newborn guinea pigs to develop the delayed type hypersensitivity was investigated by active sensitization with $10 \mathrm{mg}$ of heat-killed BCG, and also by the local or systemic passive transfer with granulomatous spleen cells from adult guinea pigs sensitized to tuberculin. Local passive transfer of the sensitivity using the sensitive cell-PPD mixture was successful in one-third of the recipients. In contrast, almost all newborn recipients in the systemic (intravenous) passive transfer with sensitive cells responded to intracutaneous injection of $40 \mu \mathrm{g}$ of PPD with a substantially intensive skin reaction. In response to the active sensitization at birth, all the guinea pigs turned tuberculin positive to $40 \mu \mathrm{g}$ PPD within 7 days of age, and produced circulating antibody measurable by means of Middlebrook-Dubos's method. These observations indicate the immunological maturity of the guinea pig at birth.
\end{abstract}

\section{INTRODUCTION}

Fetal or neonatal humans and animals have been shown to have the capacity for several modalities of the immune response (Billingham et al., 1953; Fennestad and Borg-Peterson, 1957 ; Uhr et al., 1960 ; Segre and Kaeberle, 1962 ; Vargues et al., 1962 ; Silverstein et al., 1963; Sorem and Terres, 1963; Hervey, 1966). However, there have been only a few studies on the capacity of a newborn guinea pig to develop the delayed type hypersensitivity. Some attempts to induce tuberculin hypersensitivity in young guinea pigs by passive or active sensitization have been unsuccessful (Waksman and Matoltsy, 1958; Freund, 1927). On the contrary, Weiss (1958) elicited tuberculin reactions in some of guinea pigs sensitized with tubercle bacilli in their fetal lives and Uhr (1960) has succeeded in inducing the delayed type hypersensitivity to certain protein antigens in guinea pig embryos.

Because of the paucity of information, a further study on the hypersensitivity of the delayed type in neonatal guinea pigs seems justified. This communication describes results obtained with the local and the systemic passive transfer of tuberculin hypersensitivity and with active sensitization with heat-killed tubercle bacilli in newborn guinea pigs.

\section{MATERIALS AND METHODS}

Procedures of local passive transfer: (a) Preparation of donor cells: Adult albino guinea pigs weighing 400 to $450 \mathrm{~g}$ were sensitized to tuberculin allergy by an intramuscular injection of $10 \mathrm{mg}$ of heat-killed human type tubercle bacilli (Aoyama B strain) in $0.5 \mathrm{ml}$ of liquid paraffin. Thus immunized guinea pigs were challenged intravenously with $0.5 \mathrm{mg}$ of live BCG seven or ten days before the extirpation of spleens. A swollen

吉田 彪 (国立予防衛生研究所結核部) 
granulomatous spleen weighing 3.5 to $5.0 \mathrm{~g}$ was obtained from such a challenged animal and cut into small pieces. This was sieved through a 200 -mesh stainless steel screen and washed twice in Hanks's solution by a centrifugation at 1,000 rpm for 3 minutes at room temperature. The suspension was pipetted gently before use to make single cell suspension. Approximately $95 \%$ of cells so prepared were viable when examined by staining with trypanblue and consisted mainly of large mononuclear cells as described elsewhere (Hashimoto, 1965). After counting the number of cells, PPD (Purified Protein Derivative from the culture of human type tubercle bacilli) was added to the cell suspension to make cell-PPD mixture containing $3.6 \times 10^{6}$ cells and $40 \mu \mathrm{g}$ PPD in $0.1 \mathrm{ml}$ of the mixture. Normal spleen cell mixture was made in the same way with $3.6 \times 10^{6}$ cells from normal spleen and $40 \mu \mathrm{g}$ PPD.

(b) Recipient new born guinea pigs: For mating, two adult male guinea pigs were placed in a cage with three or four females. Pregnant animals were segregated individually for delivery. Newborn guinea pigs within $24 \mathrm{hr}$ after birth were used as the recipients of cell mixtures.

(c) Procedure of i.c. injections: Newborn animals were injected intracutaneously with $0.1 \mathrm{ml}$ of the mixture of sensitive cells and PPD in one frank and with the same amount of normal cells mixed with PPD in the other frank. The longest and shortest diameters of redness of the inflammatory skin reaction were measured at 24 and 48 $\mathrm{hr}$ after the intracutaneous injection of these mixtures, but only the mean of both diameters at $24 \mathrm{hr}$ represents the datum in the present experiment. Because, in general, reactions at $48 \mathrm{hr}$ were substantially smaller than at $24 \mathrm{hr}$ but the sizes of reaction in relation to control mixtures remained the same.

Procedures of systemic passive transfer: Donor cells and recipient newborn animals were prepared in a similar way as described in the methods of local passive transfer. Five-tenths to $1.0 \mathrm{ml}$ of the sensitive cell suspension with a concentration of $2 \times 10^{8}$ cells/ml was injected intravenously into newborn guinea pigs, of which tuberculin reactions were tested simultaneously by the i. c. injection of $40 \mu \mathrm{g}$ PPD. One or two neonatal animals of each litter were used as the non-transferred controls.

Several adult guinea pigs were also used as recipients of the local and systemic passive transfer so that tuberculin reactivity could be compared between adult and neonatal animals.

Procedures of active sensitization: Neonatal guinea pigs were sensitized actively with $10 \mathrm{mg}$ of heat-killed BCG in $0.5 \mathrm{ml}$ of saline solution; $0.2 \mathrm{ml}$ was injected into the muscle of each thigh and $0.05 \mathrm{ml}$ into each hind food pad. At 7 days of age they were skin-tested with $40 \mu \mathrm{g}$ of PPD. One or two animals of each litter were left unimmunized at birth but skin-tested with the same amount of PPD at 7 days of age. In one experiment, the immunized animals were tested for skin reactivity at 5 days of age.

All actively sensitized guinea pigs were bled to death at 1 or 2 weeks of age in order to take serum samples. Circulating antibody activity of all sera was assayed by modifications of the hemagglutination and the hemolysis procedures of Middlebrook and Dubos $(1948,1950)$. Sheep erythrocytes were washed three times in $\mathrm{pH} 7.4$ isotonic veronal buffer containing $0.0005 \mathrm{M}$ of $\mathrm{MgCl}_{2}$ and $0.00015 \mathrm{M}$ of $\mathrm{CaCl}_{2}$, which was used as the diluent for all the reagents (Mayer et al., 1948). After the last centrifugation of the cell suspension at $2,000 \mathrm{rpm}$ for 20 minutes, one volume of packed cells was resuspended in 60 volumes of 30 -fold diluted OT (Old Tuberculin) whose $\mathrm{pH}$ had been adjusted to 7.4, and the suspension of cells was incubated for $2 \mathrm{hr}$ at $37 \mathrm{C}$. The cells were centrifuged, washed twice and resuspended in 200 volumes of the buffer 
to make a $0.5 \%$ suspension of sensitized cells. Subsequent procedures of hemagglutination and hemolysis were carried out with falling two-fold dilutions of all sera according to the original method of Middlebrook and Dubos (1948, 1950). The antibody titer is expressed as the logalithm to the base 2 of the reciprocal of end point serum dilution. Reduction of sera by 2-mercaptoethanol was accomplished according to the method of Deutsch and Morton (1957).

Histological examination of skin reactions: Specimens of the skin test sites were fixed in $10 \%$ formallin and embedded in paraffin. Sections were stained with hematoxylineosin and observed by light microscope.

Both Old Tuberculin and Purified Protein Derivative used here were made and supplied to us by the Tuberculin Division of the Department of Tuberculosis in the National Institute of Health, Tokyo.

\section{RESULTS}

\section{Local Passive Transfer Experiment}

The results obtained from the local passive transfer of tuberculin hypersensitivity in newborn and adult guinea pigs are summarized in Fig. 1.

Local passive sensitization was successful in about one-third of neonatal recipients;

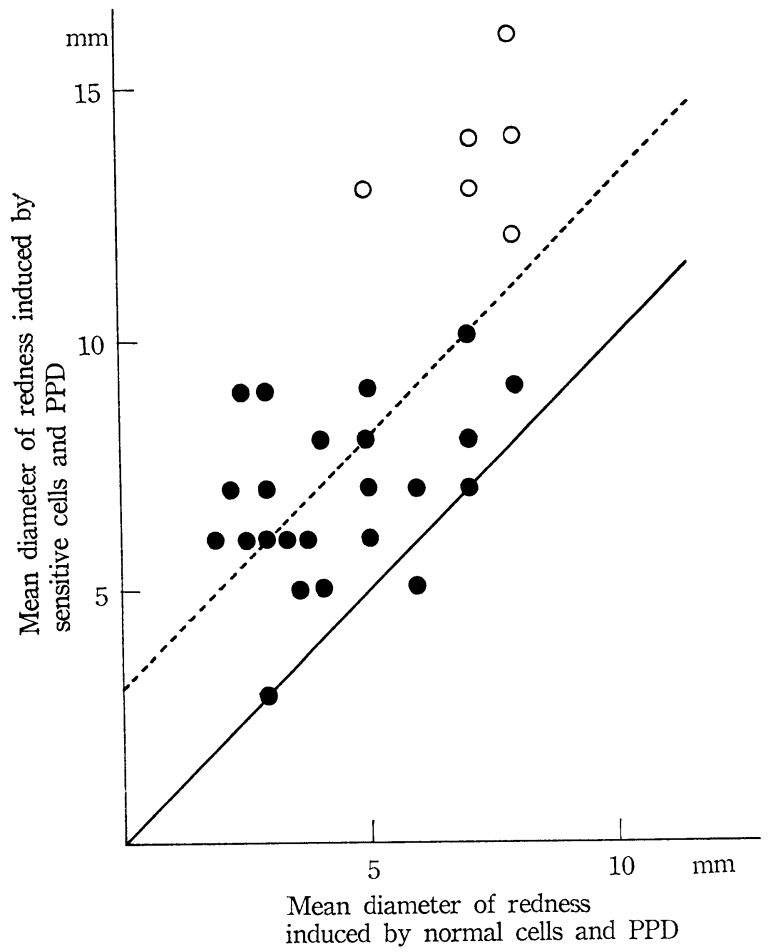

Fig. 1. Local passive transfer of tuberculin hypersensitivity in newborn guinea pigs ( ) as compared with that in adult ones (O). $3.6 \times 10^{6}$ cells and $40 \mu \mathrm{g}$ PPD were mixed to make $0.1 \mathrm{ml}$ of the mixture. Reactions were read at $24 \mathrm{hr}$. Diameter is the mean of the shortest and the longest diameters of redness. 
7 out of 23 animals showed larger reactions by more than $4 \mathrm{~mm}$ in diameter to the mixture of sensitive cells than to the normal cell mixture, as indicated in an area above the dotted line in the figure.

When skin reactions to the sensitive and normal cell mixtures in a recipient are compared macroscopically with each other, a difference smaller than $4 \mathrm{~mm}$ in mean diameter is considered insignificant.

In contrast, when the same local passive transfer was performed in mature guinea pigs, all of 6 adult recipients showed substantially stronger reactions to the sensitive cell mixture than to the normal one. In addition, reactions at $24 \mathrm{hr}$ to the sensitive cell mixture in mature recipients (average of 6 animals, $13.6 \mathrm{~mm}$ ) were significantly larger than those in neonatal recipients (average of 23 animals, $6.9 \mathrm{~mm}$ ). Reactions to the normal cell mixture both in newborn and adult recipients showed the same intensity. The nonspecific response produced by the intradermal injecton of the cell suspensions precluded an attempt to measure the specific reactions earlier, nevertheless reactions observed were of the delayed type as described in the report of Metaxas and MetaxasBuehler (1955).

\section{Systemic Passive Transfer Experiment}

The result of this type of transfer experiment was more clear-cut than that of the above-mentioned local passive transfer. Fig. 2 shows the successful passive sensitization to tuberculin hypersensitivity in newborn guinea pigs. Five out of 30 neonatal recipients have given relatively smaller reactions than the rest; in fact the body weight of these weakly sensitive animals were in general less than $75 \mathrm{~g}$ at birth. Nevertheless, three recipients in the group weighing less than $75 \mathrm{~g}$ gave skin reactions of 7,7 , and $8 \mathrm{~mm}$ at $24 \mathrm{hr}$ in mean diameters, which were significantly larger than nonspecific irritations produced by intracutaneous injections of $40 \mu \mathrm{g}$ PPD in neonatal controls.

On the other hand, all animals but one weighing more than $75 \mathrm{~g}$ at birth gave clearly the delayed type skin reaction to $40 \mu \mathrm{g}$ PPD (average ; $11.3 \mathrm{~mm}$ ) at $24 \mathrm{hr}$.

The delayed type skin reactions in neonatal recipients were nevertheless small in comparison with those seen in passively sensitized adult animals as shown in Fig. 2. The average diameter of redness elicited in adult guinea pigs was $18.0 \mathrm{~mm}$ at $24 \mathrm{hr}$.

No visible reaction was observed at $4 \mathrm{hr}$ after the intradermal injection of PPD in any recipient.

In another set of experiment, recipient guinea pigs to which sensitive cells were transferred were skin-tested not only immediately but also $24 \mathrm{hr}$ after the cell transfer. As shown in Table 1, the passively transferred skin reactivity in newborns disappeared within $24 \mathrm{hr}$ after the transfer, conversely, adult recipients kept their skin reactivity for more than $24 \mathrm{hr}$.

Microscopical investigations of the elicited delayed type skin reactions revealed that cell infiltration was remarkable at $24 \mathrm{hr}$; polymorph nuclear cells were predominant in the upper dermis but mononuclear infiltration was predominant in the deeper layers or around the subcutaneous venules, as shown in Figs. 5, and 6 .

The histologic picture of the $48 \mathrm{hr}$ reaction did not differ essentially from that of the $24 \mathrm{hr}$ reaction.

\section{Active Sensitization}

All guinea pigs immunized at birth with $10 \mathrm{mg}$ of heat-killed BCG gave positive skin reaction when skin-tested with $40 \mu \mathrm{g}$ of PPD one week later, as shown in Fig. 3. 


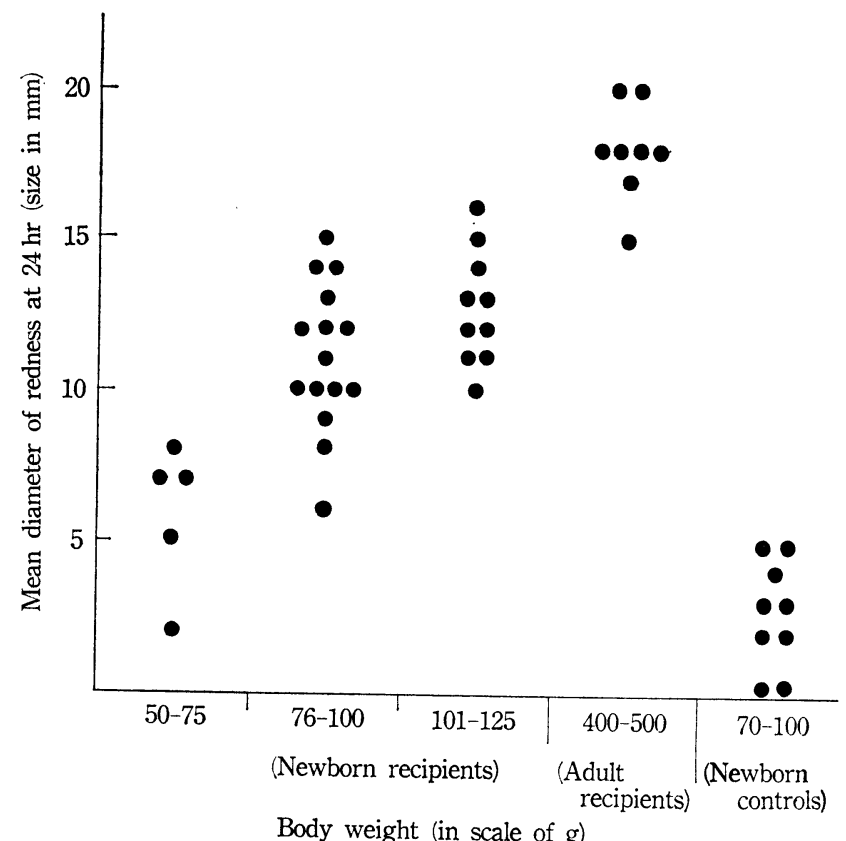

Fig. 2. Systemic passive sensitization to tuberculin hypersensitivity in newborn and adult guinea pigs. $1-2 \times 10^{8}$ cells were injected i. v. Skin reactions were tested with $40 \mu \mathrm{g}$ of $\mathrm{PPD}$.

Table 1. Tuberculin reactions elicited with $40 \mu \mathrm{g}$ PPD in newborn and adult recipients immediately after and one day after the granulomatous spleen cell transfer

\begin{tabular}{|c|c|c|c|c|}
\hline \multirow{2}{*}{\multicolumn{2}{|c|}{$\begin{array}{l}\text { Body weight } \\
\text { of recipient } \\
\text { (g) }\end{array}$}} & \multirow{2}{*}{$\begin{array}{l}\text { No. of cells } \\
\text { injected } \\
\text { i. v. }\end{array}$} & \multicolumn{2}{|c|}{$\begin{array}{l}\text { Tuberculin reactions to } 40 \mu \mathrm{g} \text { PPD } \\
\text { at } 24 \mathrm{hr} \text { in } \mathrm{mm} \text {. }\end{array}$} \\
\hline & & & immediately after & one day after \\
\hline \multirow{7}{*}{ Newborns } & 80 & \multirow{4}{*}{$1.5 \times 10^{8}$} & $9 \times 10$ & $0 \times 0$ \\
\hline & 80 & & $10 \times 10$ & $0 \times 0$ \\
\hline & 85 & & $8 \times 10$ & $4 \times 4$ \\
\hline & 85 & & $12 \times 12$ & $3 \times 3$ \\
\hline & 50 & & $0 \times 0$ & $2 \times 2$ \\
\hline & 65 & 0 & $0 \times 0$ & $0 \times 0$ \\
\hline & 80 & & $4 \times 4$ & $0 \times 0$ \\
\hline \multirow{3}{*}{ Adult } & 310 & & $17 \times 18$ & $16 \times 16$ \\
\hline & 380 & $3.2 \times 10^{8}$ & $14 \times 16$ & $13 \times 14$ \\
\hline & 390 & & $17 \times 18$ & $14 \times 16$ \\
\hline
\end{tabular}

The body weight of them ranged from 80 to $160 \mathrm{~g}$ at 1 week of age, but the appearance of these reactions did not show any correlation with the variation of body weight.

Furthermore, a litter of guinea pigs sensitized at birth were skin-tested with $40 \mu \mathrm{g}$ $\mathrm{PPD}$ at 5 days of age and they could also give positive delayed reactions ; mean diameters 


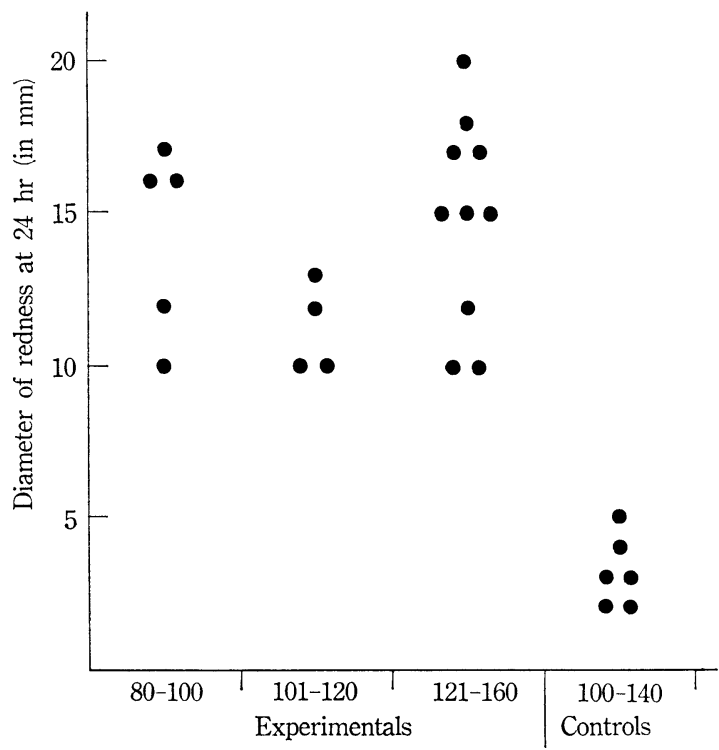

Body weight $(\mathrm{g})$ at 1 week after birth

Fig. 3. Tuberculin reaction in guinea pigs at 1 week after the sensitization at birth. Sensitizing antigen : $10 \mathrm{mg}$ of heat killed BCG in liquid paraffin. Skin testing antigen : $40 \mu \mathrm{g}$ of PPD.

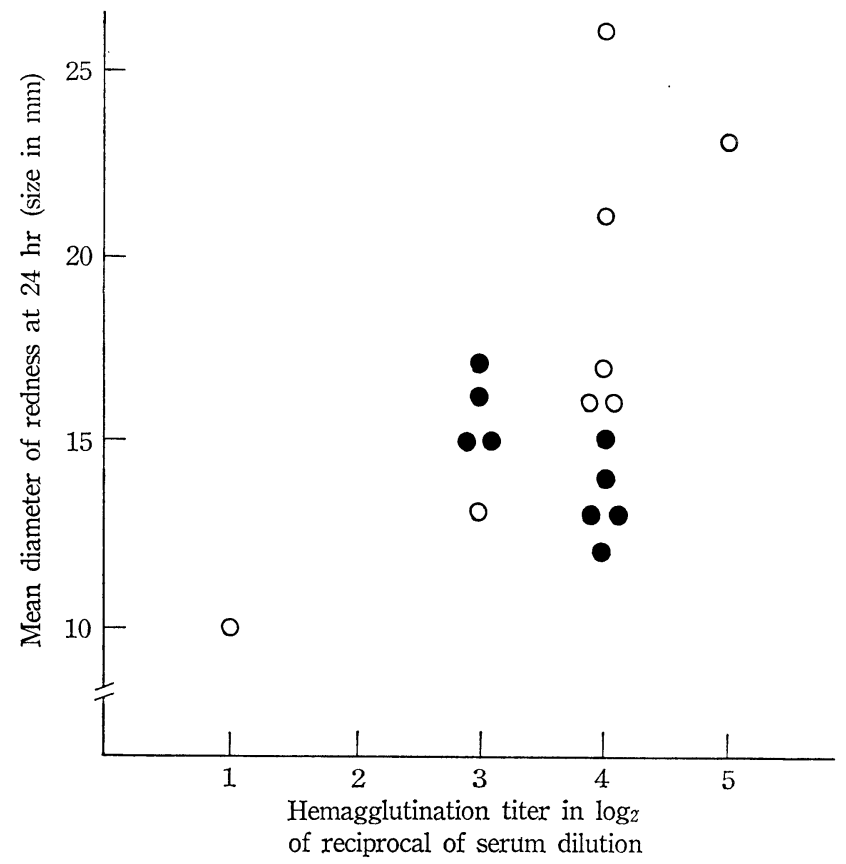

Fig. 4. Hemagglutination titers and tuberculin skin reactions in young guinea pigs at one (O) or two (O) weeks after the neonatal sensitization with heat-killed tubercle bacilli. Hemagglutinating antibody activity was completely lost by the reduction with 2 -mercaptoethanol. 


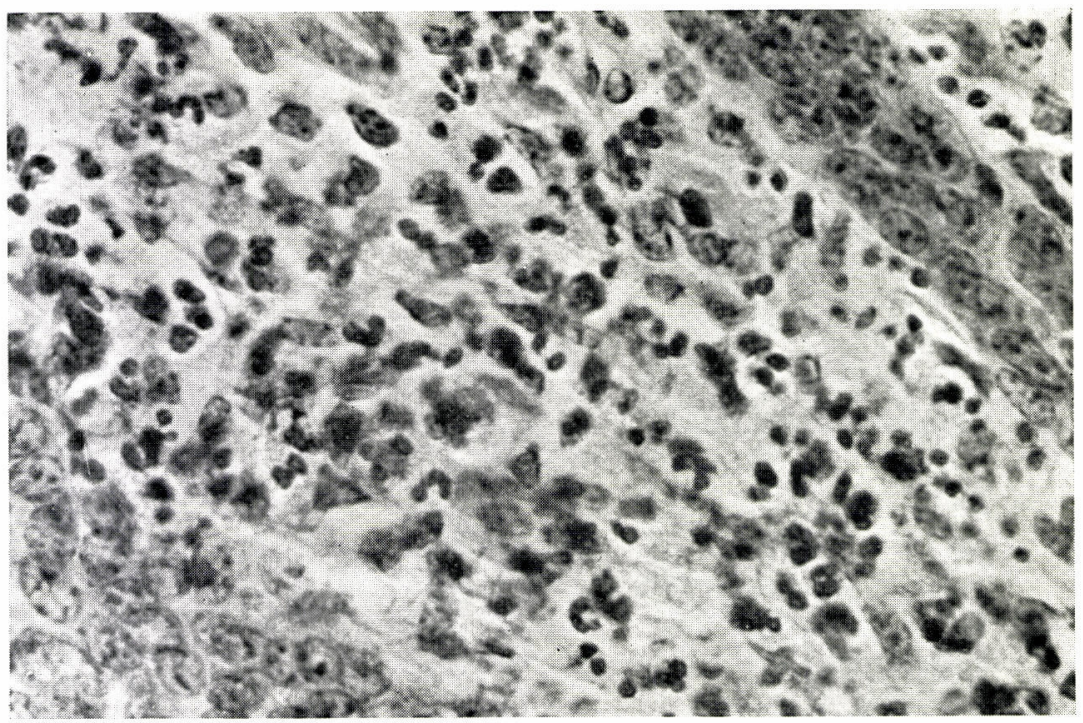

Fig. 5. Tuberculin reaction at $24 \mathrm{hr}$ elicited with $40 \mu \mathrm{g}$ PPD, in newborn guinea pig sensitized passively. (1) Remarkable cell infiltration just under the epidermis. Neutrophils are predominant. H. E. stain. $\times 400$

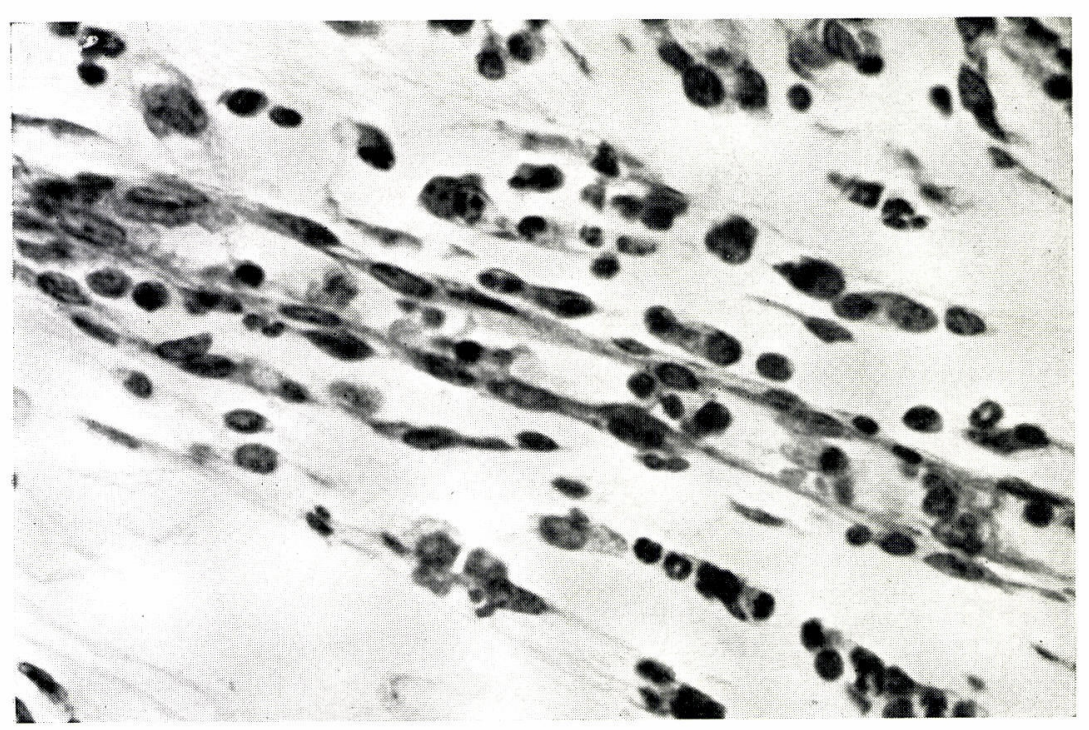

Fig. 6. Tuberculin reaction site in newborn guinea pig sensitized passively. (2) Predominant mononuclear infiltration surrounding a venule in the deeper dermis. H. E. stain. $\times 400$ 
of reactions elicited in them were $12,12,13$, and $14 \mathrm{~mm}$ at $24 \mathrm{hr}$. These reactions elicited in one-week-old animals were weak with regard to the intensity of redness and induration in comparison with the usual reactions seen in actively sensitized adult animals.

Delayed type skin reactions at 2 weeks after the neonatal immunization were in general stronger than at 1 week (Fig. 4).

Circulating antibody was also detected by the modified method of MiddlebrookDubos's hemagglutination procedures in young guinea pigs one week after the neonatal sensitization, although hemolytic antibodies were not demonstrated in the same sera.

When hemagglutination titers at one and two weeks after birth are compared with the diameters of the delayed type skin reactions at respective times shown in Fig. 4, there is a slight parallelism between humoral antibody titers and skin reactivities, showing that if sensitized strongly at birth guinea pigs have the capacity to produce both humoral and cellular antibodies simultaneously.

No residual antibody activity was demonstrated after the reduction of sera with 2-mercaptoethanol. This may provide the interpretation that almost all humoral antibodies detected may be classified as the large molecular ones, although ultracentrifugation studies should be carried out for further confirmation.

\section{DISCUSSION}

The present findings are adverse to the report by Waksman and Matoltsy (1958) : while they failed in the passive sensitization of newborn or young guinea pigs to tuberculin hypersensitivity, we have succeeded in this using local and systemic passive transfer methods. Their failure of passive transfer might be caused by several factors such as the followings. Firstly, tht local passive transfer, that is to inject sensitive cells mixed with antigen into the skin of normal recipients, is less adequate for the passive sensitization than the systemic passive transfer, to inject sensitive cells mixture intravenously or by other general routes into recipient, at least when newborn guinea pigs should be used as recipients of cells. It is because the nonspecific irritation caused by the intradermal injection of cells makes it difficult to judge the weak positive reactions elicited with the sensitive cells mixed with antigen. Secondly, recipients used in their experiment were only four newborn or young guinea pigs, too small number to obtain any decisive conclusions. Lastly, cells used in the present experiments, granulomatous spleen cells, could be more efficacious to sensitize recipients passively than peritoneal exudate cells used in their experiments. But this has not yet been proved.

In the present experiments, it is true that the passive transfer of tuberculin hypersensitivity by the intravenous injection of sensitive cells was successful in almost all neonatal recipients, but the skin reactivity transferred in them was distinctly weaker than that in adult recipients. On the other hand, it seems likely on the basis of considerable immunologic evidences that the transferred donor cells are primarily and directly responsible at least for the initial specific step of skin reactions without the participation of recipient cells or some factors, so that the number of cells transferred and the dose of skin-testing antigen are the decisive variables which determine the intensity of skin reactions in recipients. If this hypothesis is valid, why are the elicited skin reactions in newborn guinea pigs weaker than those in adult recipients despite the relatively large amount of sensitive cells and antigen injected into neonatals? To answer this question, the author have to investigate the subsequent steps in the skin reaction 
which follow the initial step of specific interaction between sensitive cells and antigen in the test site. In these unknown steps cells or factors of the recipient itself could play an important role to reinforce the inflammatory reaction. Any details relating to the later setps are still inavailable, therefore the author can state at present only that the quantitatively insufficient capability of newborn guinea pigs to respond in those steps of delayed skin reactions is the cause of the weak reactions induced in newborn recipients

In this regard it is possible but unlikely that such an incompetency of newborn animals is the failure of the cellular environment in these animals to permit differentiation of the transferred cells towards mature macrophages, as pointed out by Dixon et al. (1956) and Waksman et al. (1958); from our findings it is obvious that the relative incompetency in neonatals is not a complete failure of a mechanism in the delayed skin reaction but the quantitative insufficiency in the skin reactivity.

In order to analyze properly the mechanism of the tuberculin allergy, it is the most important requisite to use completely normal animals as the recipient of the sensitized donor cells. However since a germ-free guinea pig can not be obtained easily, we have to admit that most adult animals may be exposed to some external antigens or infections, consequently investigators are forced to test the tuberculin reaction of normal recipients before the transfer experiment at the risk of sensitizing these animals with a single injection of skin-testing antigens. (Yoshida et al, 1966a)

From this point of view, if one uses neonatal animals as the recipient of passive senisitization, one can neglect to infections or sensitization to external antigens, in addition to our convenience the tuberculin sensitivity is not passively acquired by fetus the placenta of a hypersensitive mother. (Weiss, 1958)

Before performing the present experiments, the author speculated that the skin reactivity transferred passively in newborn recipients probably might continue longer than that in adult animals because of the immature capacity of neonatal animals to reject the transferred cells which are homologous to the recipient. The fact was that the transferred sensitivity did not last more than one day in newborn guinea pigs, contrariwise that of adult recipients used to maintain during about three days until the rejection of sensitive donor cells. This may be explained that the guinea pig at birth is able to reject homologous cells as completely as adult animals, and that the transferred sensitivity, in addition, is too weak to be kept by newborn animals more than one day.

The results of active sensitization to tuberculin hypersensitivity in newborn guinea pigs in the present experiments agree well with the reports of Uhr (1960) and Weiss (1958) concerning the actively sensitized delayed type hypersensitivity in guinea pig embryos and also coincide with the effects of the neonatal thymectomy on the tuberculin hypersensitivity in guinea pigs (Yoshida et al., 1966 b). All these facts suggest that the guinea pig is immunologically mature at birth, at least in regard to the delayed type allergy.

From these results it becomes more important to study the active sensitization of fetal guinea pigs and the influence of the fetal thymectomy in guinea pigs so as to clarify the immunological development in this species.

\section{ACKNOWLEDGEMENT}

The author wishes to thank Dr. T. Hashimoto for his useful discussions and advices, Dr. Y. Egashira, chief of the Department of Pathology, N. I. H., Tokyo for the histologic findings, and Mr. S. Haga for his technical assistance. 


\section{REFERENCES}

Billingham, R. E., BRENT, L. AND MEDAWAR, P. B. (1953): Actively acquired tolerance of foreign cells. Nature, 172, 603-606.

DEUTSCH, H. F. AND MORTON, J. I. (1957) : Dissociation of human serum macro-globulins. Science, $125,600-601$.

DiXon, F. J. AND WeIGLE, W. O. (1956): The nature of the immunologic inadequacy of neonatal rabbits as revealed by cell transfer studies. J. Exptl. Med., 105, 75-83.

FenNestad, K. L. AND BORG-PETERSON, C. (1957) : Leptospira antibody production by bovine foetuses. Nature, 180, 1210-1211

FREUND. J. (1927): The influence of age on skin sensitiveness of tuberculous guinea pigs. J. Immunol., 13, 285-288.

HASHIMOTO, T. (1965): Passive tranfer of the delayed type hypersensitivity with live cells. Proc. Japan. Soc. Reticuloendothelial Syst., 5, 108-117. (text in Japanese)

Hervey, E. J. (1966): The immunological response to a killed bacterial antigen in foetal and neonatal rats. Immunology, 11, 589-596.

MAYeR, M. M., CROFT, C. C. AND Gray, M. M. (1948) : Kinetic studies on immune hemolysis : I. A method. J. Exptl. Med., 88, 427-444.

Metaxas, M. N. AND Metaxas-BuehleR, M. (1955) : Studies on the cellular transfer of tuberculin sensitivity in the guinea pig. J. Immunol., 75, 333-347.

MidDlebROOK, G. AND DUBOS, R. J. (1948): Specific serum agglutination of erythrocytes sensitized with extracts of tubercle bacilli. J. Exptl. Med., 88, 521-528.

MIDDLEBROOK, G. (1950): A hemolytic modification of the hemagglutination test for antibodies against tubercle bacillus antigens. J. Clin. Invest., 29, 1480-1485.

SEGRE, D. AND KaEBERLE, M. L. (1962) : The immunologic behaviour of baby pigs. II. Production of antibodies in newborn pigs. J. Immunol., 89, 790-793.

Silverstein, A. M., UhR, J. W., KRANer, K. L. AND Lukes, R. J. (1963) : Foetal response to antigenic stimulus. II. Antibody production by foetal lamb. J. Exptl. Med., 117, 799-812.

SOREM, G. L. AND TERRES, G. (1963) : The temporal relationship of acquired tolerance and the immune response following injection of bovine serum albumin into neonatal mice. J. Immunol., 90, 217-223.

Uhr, J. W., Danis, J. and Neumann, C. G. (1960) : Delayed-type hypersensitivity in premature neonatal humans. Nature, 187, 1130-1131.

UHR, J, W. (1960): Development of delayed-type hypersensitivity in guinea pig embryos. Nature, 187, 957-959.

VARGues, R., MORAND, B. AND LORTholary, J. (1962) : Activités bactériolytique et bactéricide des animaux nouveau-nés. C. R. Soc. Biol., 156, 879-882.

WAKSMAN, B. H. AND MATOLTSY, M. (1958): Quantitative study of local passive transfer of tuberculin sensitivity with peritoneal exudate cells in the guinea pig. J. Immunol., 81, 235-241.

WEISS, D. W. (1958) : Inhibition of tuberculin skin hypersensitivity in guinea pigs by injection of tuberculin and intact tubercle bacilli during fetal life. J. Exptl. Med., 108, 83-104.

Yoshida, T. AND HASHIMOTO, T. (1966a): Induction of delayed hypersensitivity in guinea pigs with Old Tuberculin or Purified Protein Derivative. Japan. J. Med. Sci. Biol., 19, 259-262.

Yoshida, T. AND Hashimoto, T. (1966 b) : Delayed skin reactions in guinea pigs thymectomized at birth. Japan. J. Allergy, 15, 775-779. (text in Japanese with Englisn summary) 